\title{
Biology, Information, Society
}

\author{
Petar Jandrić, ${ }^{1,2}$
}

Accepted: 19 February 2021 / Published online: 17 March 2021

(c) The Author(s), under exclusive licence to Springer Nature Switzerland AG 2021

Keywords Postdigital · Biology · Information · Society · Covid-19 · Pandemic . Knowledge · Education · Knowledge ecology $\cdot$ Bioinformation $\cdot$ Technoscience · Convergence $\cdot$ Really useful knowledge $\cdot$ Epistemology

\section{Really Useful Knowledge in the Postdigital Age}

In 2020, the Covid-19 pandemic radically changed our way of life. From my March editorial inviting the community to "explore all imaginable aspects of this large social experiment that the Covid-19 pandemic has lain down in front of us' (Jandric 2020: 237), to the September issue with almost 60 articles on various aspects of the pandemic, ${ }^{1}$ the Postdigital Science and Education community has joined global research efforts to make sense of the pandemic. In April, the journal was approached by the World Health Organization to share preprints, and selected articles have since been indexed in the US National Library of Medicine's Nature Public Health Emergency Collection. ${ }^{2}$ Several articles have been acknowledged by UNESCO for their contribution to advancing Sustainable Development Goals (SDGs). ${ }^{3} \mathrm{~A}$ few articles, such as 'Online University Teaching During and After the Covid-19 Crisis: Refocusing Teacher Presence and Learning Activity' (Rapanta et al. 2020), and 'Post-Covid-19 Education and Education Technology "Solutionism": a Seller's Market' (Teräs et al. 2020), have attracted tens of thousands of readers, many quotations, and have been translated into diverse languages from Turkish to Chinese. At the beginning of 2021, we can say that the Postdigital Science and Education community has made itself reasonably useful in the struggle against the

\footnotetext{
${ }^{1}$ See Postdigital Science and Education, 2(3), https://link.springer.com/journal/42438/volumes-andissues/2-3. Accessed 12 February 2021.

${ }^{2}$ See https://www.ncbi.nlm.nih.gov/pmc/?term=Nature+Public+Health+Emergency+Collection. Accessed 12 February 2021.

${ }^{3}$ See https://www.springernature.com/gp/researchers/sdg-programme/sdg16. Accessed 9 March 2021.
}

Petar Jandrić

pjandric@tvz.hr

1 Zagreb University of Applied Sciences, Zagreb, Croatia

2 University of Wolverhampton, Wolverhampton, UK 
pandemic. Today, the million (insert your favourite currency) question is: How can we make our work even more useful in the future?

This phrase immediately brings to mind Richard Johnson's (1981) seminal chapter about differences between 'useful knowledge' focused to educating productive workers for capitalism, and 'really useful knowledge' focused to emancipation and social justice. Forty years after Johnson, I will shamelessly repurpose his metaphor to assert that in our pandemic moment, useful knowledge is about establishing a new normal-developing and distributing vaccines, finding the best ways of online teaching and learning, and so on. In our postdigital condition, really useful knowledge is about deep and wide changes in understanding of our reality, and about the relationships of these changes to emancipation and social justice. While postdigital really useful knowledge cannot be thought of without the pandemic, it reaches beyond the pandemic to the point where the pandemic experience is transformed from an object of research to an intrinsic part of our theories, approaches, research methodologies, and social struggles.

Thankfully, pre-pandemic postdigital theory offers many 'hooks' into which such research could get a hold. When we planted these hooks, we never imagined that they would be taken up so quickly. Yet the disastrous pandemic, which has caused so much suffering and death, has also brought about a positive side-effect-it has radically hastened development of scientific research. Building on useful knowledge developed in the heat of the pandemic, the Postdigital Science of Education journal and book series now seek research directions, old and new, that can be understood as seeds of postdigital really useful knowledge.

\section{Biology, Information, Society}

At the dawn of the millennium, it has become obvious that the twentieth century was the century of physics and that the twenty-first century will be the century of biology. Already in 2007, Dyson wrote: '[b]iology is now bigger than physics, as measured by the size of budgets, by the size of the workforce, or by the output of major discoveries (...). Biology is also more important than physics, as measured by its economic consequences, by its ethical implications, or by its effects on human welfare.' (Dyson 2007) In traditional classifications, physics refers to knowledge about the non-living world (computers, energy, and so on); and biology refers to knowledge about the living world (evolution, structure of genome, and so on). However, the twenty-first century shift in relative importance between physics and biology does not imply the replacement of one with the other. Rather, we are now witnessing a rapid convergence between physics and biology 'that harnesses both the results of the information and new biology revolutions and brings them together in a powerful alliance' (Peters 2012: 105). 'Biology' practices, such as genome mapping and editing, cannot be thought of without computers, and 'physics' developments, such as new energy sources, cannot be thought of without consideration of their implications on Earth's ecosystem. Traditional distinctions between science and engineering are also evaporating, as technologies have become intrinsic parts of yesterday's 'fundamental' research. 
The convergence between biology and information and the convergence between science and technology are closely followed by numerous lower-order convergences such as the emergence of bioeconomy (Peters et al. 2021a, 2021b). This gives rise to a wide array of ethical, social, and other issues and marks 'new research directions in our sciences, inspired by social and cultural changes and enabled by technological developments, at our current historical conjecture' (Peters et al. 2020). Some key challenges of today, from algorithmic/surveillance capitalism (Peters 2012; Zuboff 2019), the emerging forms of bioeconomy, through to the Covid-19 pandemic, cut across traditional borders of biology, information, and society. It is at these intersections that really useful knowledge is located in our postdigital reality.

One of the first steps towards exploring this complex reality is to ask the question of knowledge. Biodigital and technoscientific convergences transcend traditional research methodologies, so a group of us has recently started to explore the wider notion of biodigital knowledge ecologies:

Biodigital knowledge ecologies are theoretical and practical (praxis); scientific and technical (technoscience); analogue and digital (postdigital); biological and informational (bioinformational); and political and economic (bioinformational capitalism). Biodigital knowledge ecologies are much more than listed elements, and they also contain various combinations of listed and unlisted elements (e.g., biodigital technoscience). (Peters et al. 2021a)

Knowledge is dialectically intertwined with education, and all education is politics, so we also embarked on exploration of 'new postdigital ecopedagogies that are critical and creative, certain and indeterminate, transparent and opaque, and that accept and negotiate the contamination of the constantly shifting borders between humans, machines, nature, nonhuman animals, and objects' (Jandrić and Ford 2020).

These reconfigurations of biology, information, and society are closely related to our understanding of postdigital humans (Fuller 2020; Savin-Baden 2021), and to new transformations of belief and religious practice (McLaren 2020; Reader and Savin-Baden 2021; Trozzo 2020). Perhaps less obviously, but just as importantly, these new reconfigurations underlie 'traditional' research topics as diverse as epistemology of truth/deceit (MacKenzie et al. 2021), online behaviours (Koole et al. 2021), and learning (Fawns et al. 2021; Gallagher et al. 2020; Goetz 2020; Networked Learning Editorial Collective 2020). They also have implications for postdigital thinking (Ryberg et al. 2021), living (Lacković 2020), postdigital spaces (Calder and Otrel-Cass 2020), political economy (Arantes 2020), and activism (Bauwens and Jandrić 2021). In our postdigital-biodigital reality (Peters et al. 2021a, 2021b), no aspect of human activity remains intact.

\section{What Comes Next?}

This brief overview of current and forthcoming Postdigital Science and Education articles and books indicates the community's immediate research interests. Yet how do these new reconfigurations of biology, information, and society fit with existing 
postdigital theory? In our mission statement article for Postdigital Science and Education, we wrote: '[t]he postdigital is hard to define; messy; unpredictable; digital and analog; technological and nontechnological; biological and informational' (Jandrić et al. 2018: 895). Early postdigital theorists such as Kim Cascone, and mainstream responses to the Covid-19 pandemic, are still predominantly focused to the digital-analog side of the definition (Cascone and Jandrić 2021; Jandrić et al. 2020). Yet studies of the relationships between biology, information, and society have closely followed the development of various bioinformational, technoscientific, and other convergences (Bainbridge and Roco 2006; Williamson 2019), and the Covid-19 pandemic has caused a rapid growth of research in the field (Johnson et al. 2020; Pickersgill 2020).

Should we all jump on this old-but-new, exciting research train lured by the promise of epistemic, low-hanging fruit we are hoping to find in pastures new and unexplored? This ironic question is at least partially misleading, because relationships between biology, information, and society are hugely complex, and low-hanging fruit seems scarcer than hen's teeth. Epistemically, we should beware of putting all our eggs into the biodigital basket—really useful knowledge arrives in various shapes and hues, and 'the biodigital is an important aspect of the postdigital idea, but it is far from the only one' (Peters et al. 2021b). However, the Covid-19 pandemic has given us a strong reminder of the recent bioinformational and technoscientific convergences and an important message that postdigital really useful knowledge lies at the intersections between biology, information, and society. Whatever our research focus, this message needs to be taken seriously.

\section{References}

Arantes, J. A. (2020). The Servitization of Australian K-12 Educational Settings. Postdigital Science and Education. https://doi.org/10.1007/s42438-019-00097-0.

Bainbridge, W. S., \& Roco, M. C. (2006). Managing nano-bio-info-cogno innovations: Converging technologies in society. Dordrecht: Springer.

Bauwens, M., \& Jandrić, P. (2021). The Seeds of The Commons: Peer-to-Peer Alternatives for Planetary Survival and Justice. Postdigital Science and Education. https://doi.org/10.1007/s42438-021-00218-8.

Calder, N., \& Otrel-Cass, K. (2020). Space exploration: Approaches to inhabiting digital spaces and their influence on education. Postdigital Science and Education. https://doi.org/10.1007/s42438-02000199-0.

Cascone, K., \& Jandrić, P. (2021). The failure of failure: Postdigital aesthetics against technomystification. Postdigital Science and Education. https://doi.org/10.1007/s42438-020-00209-1.

Dyson, F. (2007). Our biotech future. The New York Review, 19 July. https://www.nybooks.com/articles/ 2007/07/19/our-biotech-future/. Accessed 17 February 2021.

Fawns, T., Aitken, G., \& Jones, D. (Eds.). (2021). Online postgraduate education in a postdigital world. Springer.

Fuller, S. (2020). Schrödinger's 'What Is Life?' As Postdigital Prophecy. Postdigital Science and Education. https://doi.org/10.1007/s42438-020-00149-w.

Gallagher, M., Breines, M., \& Blaney, M. (2020). Ontological transparency, (in)visibility, and hidden curricula: Critical pedagogy amidst contentious edtech. Postdigital Science and Education. https:// doi.org/10.1007/s42438-020-00198-1.

Goetz, G. (2020). The odyssey of pedagogies of technoscientific literacies. Postdigital Science and Education. https://doi.org/10.1007/s42438-020-00188-3. 
Jandrić, P. (2020). Postdigital research in the time of Covid-19. Postdigital Science and Education, 2(2), 233-238. https://doi.org/10.1007/s42438-020-00113-8.

Jandrić, P., \& Ford, D. (2020). Postdigitalecopedagogies: Genealogies, contradictions, and possible futures. Postdigital Science and Education. https://doi.org/10.1007/s42438-020-00207-3.

Jandrić, P., Hayes, D., Truelove, I., Levinson, P., Mayo, P., Ryberg, T., et al. (2020). Teaching in the age of Covid-19. Postdigital Science and Education, 2(3), 1069-1230. https://doi.org/10.1007/s42438020-00169-6.

Jandrić, P., Knox, J., Besley, T., Ryberg, T., Suoranta, J., \& Hayes, S. (2018). Postdigital science and education. Educational Philosophy and Theory, 50(10), 893-899. https://doi.org/10.1080/00131857. 2018.1454000.

Johnson, M. W., Maitland, E., \& Torday, J. (2020). Covid-19 and the epigenetics of learning. Postdigital Science and Education. https://doi.org/10.1007/s42438-020-00190-9.

Johnson, R. (1981). "Really useful knowledge": Radical education and working-class culture. In R. Dale, G. Esland, R. Furgusson, \& M. MacDonald (Eds.), Education and the state volume 2: Politics, patriarchy, and practice (pp. 1790-1848). Barcombe, UK: The Falmer Press.

Koole, M., Clark, S., Hellsten-Bzovey, L.-A., McIntyre, L., \& Hendry, B. (2021). Stalked by our own devices: Cyberbullying as a boundary crossing behavior. Postdigital Science and Education. https:// doi.org/10.1007/s42438-020-00210-8.

Lacković, N. (2020). Postdigital Living and Algorithms of Desire. Postdigital Science and Education. https://doi.org/10.1007/s42438-020-00141-4.

MacKenzie, A., Bhatt, I., \& Rose, J. (Eds.). (2021). The epistemology of deceit in a postdigital era: Dupery by design. Springer.

McLaren, P. (2020). Networked religion: Metaphysical redemption or eternal regret? Postdigital Science and Education. https://doi.org/10.1007/s42438-020-00112-9.

Networked Learning Editorial Collective. (2020). Networked learning: Inviting redefinition. Postdigital Science and Education. https://doi.org/10.1007/s42438-020-00167-8.

Peters, M. A. (2012). Bio-informational capitalism. Thesis Eleven, 110(1), 98-111. https://doi. org/10.1177/0725513612444562.

Peters, M. A., Jandrić, P., \& Hayes, S. (2021a). Biodigital philosophy, technological convergence, and new knowledge ecologies. Postdigital Science and Education. https://doi.org/10.1007/s42438-02000211-7.

Peters, M. A., Jandrić, P., \& Hayes, S. (2021b). Postdigital-biodigital: An emerging configuration. Educational Philosophy and Theory. https://doi.org/10.1080/00131857.2020.1867108.

Peters, M. A., Jandrić, P., \& McLaren, P. (2020). Viral modernity? epidemics, infodemics, and the 'bioinformational' paradigm. Educational Philosophy and Theory. https://doi.org/10.1080/00131857. 2020.1744226 .

Pickersgill, M. (2020). Epigenetics, education, and the plastic body: Changing concepts and new engagements. Research in Education, 107(1), 72-83. https://doi.org/10.1177/\%2F0034523719867102.

Rapanta, C., Botturi, L., Goodyear, P., Guàrdia, L., \& Koole, M. (2020). Online university teaching during and after the Covid-19 crisis: Refocusing teacher presence and learning activity. Postdigital Science and Education, 2(3), 923-945. https://doi.org/10.1007/s42438-020-00155-y.

Reader, J., \& Savin-Baden, M. (2021). Postdigital theologies: Technology, belief, and practice. Postdigital Science and Education. https://doi.org/10.1007/s42438-020-00212-6.

Ryberg, T., Davidsen, J., Bernhard, J., \& Larsen, M. C. (2021). Ecotones: A teacher presence and learning activity. Postdigital Science and Education. https://doi.org/10.1007/s42438-020-00213-5.

Savin-Baden, M. (Ed.). (2021). Postdigital humans: Transitions, transformations and transcendence. Springer.

Teräs, M., Suoranta, J., Teräs, H., \& Curcher, M. (2020). Post-Covid-19 education and education technology 'solutionism': A seller's market. Postdigital Science and Education, 2(3), 863-868. https://doi. org/10.1007/s42438-020-00164-x.

Trozzo, E. (2020). Postdigital mediation of transcendence. Postdigital Science and Education. https://doi. org/10.1007/s42438-020-00135-2.

Williamson, B. (2019). Brain data: Scanning, scraping and sculpting the plastic learning brain through neurotechnology. Postdigital Science and Education, 1(1), 65-86. https://doi.org/10.1007/s42438018-0008-5.

Zuboff, S. (2019). The age of surveillance capitalism: The fight for a human future at the new frontier of power. New York: PublicAffairs. 